\title{
Khảo sát khả năng bảo quản thịt của hệ nhũ tương nano tinh dầu tiêu tạo thành bằng phương pháp đồng hóa tốc độ cao
}

\section{Application of pepper oil nanoemulsion by high-speed homogenization method on meat preservation}

\author{
Lý Thị Minh Hiền ${ }^{1 *}$, Tô Thị Thư ${ }^{1}$, Phạm Thị Anh Thư ${ }^{1}$, \\ Trần Thị Phương Thảo ${ }^{1}$, Đống Thị Anh Đào ${ }^{2}$

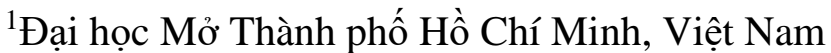 \\ ${ }^{2}$ Đại học Bách Khoa - Đại học Quốc Gia Thành phố Hồ Chí Minh, Việt Nam \\ *Tác giả liên hệ, Email: hien.ltminh@ou.edu.vn
}

\begin{abstract}
THÔNG TIN
TÓM TÁTT

DOI: $10.46223 / \mathrm{HCMCOUJS}$. tech.vi.15.1.1020.2020

Ngày nhận: 06/02/2020

Ngày nhận lại: 20/09/2020

Duyệt đăng: 17/11/2020

\section{Tù khóa:}

bảo quản thịt, hệ nhũ tương nano, tinh dầu tiêu đen, đồng hóa tốc độ cao

Tiêu đen là loại gia vị truyền thống trong nhiều món ăn tại Việt Nam, trong đó có các món chế biến từ nguyên liệu thịt với vai trò chủ yếu là tạo vị và bảo quản. Trên cơ sở đó, tinh dầu tiêu đen chứa các thành phần có hoạt tính kháng khuẩn, kháng oxi hóa, ...có thể được ứng dụng tạo thành phụ gia bảo quản thực phẩm. Trong nghiên cứu này, hệ nhũ tương nano tinh dầu tiêu đen được tạo thành bằng phương pháp đồng hóa tốc độ cao sẽ được dùng để bảo quản thịt gà và thịt heo để so sánh với các mẫu đối chứng không dùng chế phẩm này. Kết quả cho thấy, cả thịt gà và thịt heo tươi nhúng trong dung dịch nano tinh dầu tiêu đen đều có mật độ vi sinh vật hiếu khí thấp hơn các mẫu thịt tươi đối chứng (nhúng trong nước muối $1 \%$ và nước cất) với thời gian bảo quản kéo dài đến 4 ngày ở $10^{\circ} \mathrm{C}$. Với các mẫu thịt gà và thịt heo ướp gia vị, công thức ướp có bổ sung hệ nhũ tương nano tinh dầu tiêu đen cho mật độ vi sinh vật hiếu khí bé hơn mẫu ướp gia vị đối chứng (không có nano tinh dầu tiêu) và sau 9 ngày bảo quản, mật độ vi sinh vật hiếu khí của mẫu chứa nano tinh dầu vẫn bé hơn $6 \log _{10} \mathrm{CFU} / \mathrm{g}$.
\end{abstract}

Keywords:

meat preservation, nanoemulsion, black pepper essential oil, high-speed homogenization

\section{ABSTRACT}

Black pepper has been a kind of Vietnamese traditional spices for very long time. Especially, black pepper has been often utilized in Vietnamese meat products in order to preserve and give flavour. Therefore, black pepper essential oil which has bioactivities such as antimicroorganism, antioxidant, ... could be used as food preservative. In this study, black pepper essential oil nanoemulsion was formulated by high-speed homogenization then added to meat (pork and chicken) as a preservative. Initially, fresh meats dripped into nanoemulsion for 5 minutes showed lower quantity of aerobic microorganism than $1 \%$ salt solution or distilled water till 4 days at $10^{\circ} \mathrm{C}$ storage. Additionally, we cured pork and chicken in 2 ways (seasoning only (salt, sugar, food enhancer) and seasoning together with essential oil 
nanoemulsion) for 12 days. All of the curing meats containing nanoemulsion had better quality and their number of areobic microorganism cell was below 6 Log CFU/g after 9 days, while the Log CFU/g of the other samples increased over 6 after 3 days.

\section{Giới thiệu}

Tinh dầu là hỗn hợp các chất thường không ưa nước, được sinh tổng hợp chủ yếu do thực vật và được biết đến với các hoạt tính sinh học như kháng vi sinh vật, chống oxi hóa, kháng viêm, chống khối $u, \ldots$ Các loại gia vị thường được dùng trong thực phẩm như tiêu, tỏi, hành, rau gia vị,... thường chứa nhiều tinh dầu nhờ đó giúp tạo hương vị đồng thời góp phần bảo quản thực phẩm.

Tiêu là loại gia vị thường dùng trên thế giới, đặc biệt cho các sản phẩm chế biến từ thịt. Tinh dầu tiêu được chưng cất từ nguyên liệu tiêu trồng ở các vùng tại Trung Quốc được phân tích trong kết quả của Li và cộng sự (2020) có thành phần chính gồm 19 chất hóa học, có hoạt tính kháng oxi hóa và kháng vi sinh vật, tác giả cũng cho rằng loại tinh dầu này được sử dụng trong cả thực phẩm và y dược với các hoạt tính sinh học đáng quý của nó. Trong một nghiên cứu khác của Myszka, Schmidt, Majcher, Juzwa, và Czaczyk (2017), tinh dầu tiêu đen được dùng bổ sung vào xốt giúp tăng khả năng bảo quản cho rau diếp nhờ hoạt tính kháng khuẩn. Ngoài việc ức chế vi sinh vật trên rau, tinh dầu tiêu còn thể hiện hoạt tính bảo quản trên sản phẩm thực phẩm có từ nguyên liệu động vật như trong một công bố của Zhang và cộng sự (2016), kết quả của nghiên cứu này cho thấy với các nồng độ khác nhau của tinh dầu tiêu $(0,1$ hay $0,5 \%)$ đều cho hoạt tính chống oxi hóa và ức chế sự phát triển của vi khuẩn (Pseudomonas spp. và Enterobacteriaceae).

Mặc khác, tinh dầu thường khó phân tán trong nước vốn là môi trường chính của thực phẩm, do đó, nhiều biện pháp được thực hiện giúp phân tán tinh dầu tiêu đen dùng trong bảo quản thực phẩm như nhốt tinh dầu vào trong cấu trúc ưa nước hydroxypropyl-betacyclodextrin (Rakmai, Cheirsilp, Mejuto, Torrado-Agrasar, \& Simal-Gandara, 2017) hay trong gel tạo gởi gelatin và alginate (Theo Bastos, Vicente, dos Santos, de Carvalho, \& Garcia-Rojas, 2020). Phổ biến hơn cả hiện nay là tinh dầu được phân tán trong hệ nhũ tương hay nano nhũ tương sau đó bổ sung vào thực phẩm và dược phẩm. Phương pháp phân tán bằng hệ nhũ tương nano được nghiên cứu rất phổ biến cho tinh dầu tiêu đen nói riêng và tinh dầu nói chung. Với tinh dầu tiêu đen, Jimenez, Domínguez, Pascual-Pineda, Azuara, và Beristain (2018) tạo hệ nhũ tương tinh dầu tiêu đen và quế bằng các phương pháp đánh siêu âm hay đồng hóa áp suất cao, các sản phẩm nhũ tương tạo thành cho thấy có hoạt tính kháng với Listeria monocytogenes và Escherichia coli. Một nghiên cứu khác của Swathy, Mishra, Thomas, Mukherjee, và Chandrasekaran (2018), trong công bố này, tác giả tạo hệ nhũ tương nano tinh dầu tiêu đen bằng áp suất cao và phân tán chế phẩm trong môi trường nước và khảo sát khả năng kháng Pseudomonas aeruginosa, chất nhũ hóa được sử dụng là Tween 80 với tỷ lệ chất nhũ hóa và pha dầu là $1: 2$, giọt nhũ nano tạo thành có kích thước $30 \mathrm{~nm}$ với chỉ số đa phân tán 0,21 .

Các phương pháp đồng hóa tạo thành hệ nhũ tương nano chứa tinh dầu thực vật cũng được nghiên cứu nhiều trong thời gian vừa qua, chủ yếu là đồng hóa bằng áp suất cao, đồng hóa bằng sóng siêu âm hay đồng hóa cơ với tốc độ cao. Các phương pháp đồng hóa này có thể sử dụng riêng lẻ như ở các nghiên cứu dùng sóng siêu âm trong kết quả nghiên cứu của Noori, Zeynali và Almasi (2018), nhóm tác giả đã tạo hệ nano với tinh dầu gừng và đánh giá hoạt tính kháng vi sinh vật, kháng khuẩn hay trong nghiên cứu của Gharenaghadeh và cộng sự (2017) tạo nano tinh dầu xô thơm và chứng minh khả năng ức chế của hệ nhũ tương nano này với các vi sinh vật gây bệnh (Bacillus cereus, Enterococcus faecalis, Klebsiella pneumoniae, Moraxella catarrhalis). 
Phương pháp đồng hóa với tốc độ cao có thể dùng kết hợp với đánh siêu âm hay áp suất cao. Trong một nghiên cứu năm 2016 của Gharibzahedi và Mohammadnabi, để tạo thành hệ nhũ tương nano tinh dầu tầm ma với sự có mặt của chất nhũ hóa không ion (Tween 40, 60 và 80 ), quá trình đồng hóa thực hiện qua hai bước: đồng hóa tốc độ cao và tiếp theo là đồng hóa áp suất cao. Hệ nhũ tương nano tạo thành được đánh giá có kháng khuẩn với Staphylococcus aureus, Bacillus subtilis và E. coli. Sau đó, năm 2018, Ghani, Barzegar, Noshad, và Hojjati kết hợp đồng hóa tốc độ cao và đồng hóa bằng siêu âm trong quá trình tạo hệ nhũ tương nano tinh dầu quế và đánh giá hoạt tính kháng khuẩn cũng như ứng dụng chế phẩm trong bảo quản thịt bò.

Nếu không sử dụng kết hợp, phương pháp đồng hóa tốc độ cao vẫn có thể áp dụng để phá nhỏ cấu trúc giọt nhũ và tạo hệ nhũ tương nano như trong công bố của Mendes và cộng sự (2018). Với tốc độ khuấy thay đổi từ 8.000 đến 12.000 vòng/ phút, hệ nhũ tương nano có sự giảm kích thước từ hơn $300 \mathrm{~nm}$ xuống $143,13 \mathrm{~nm}$, đồng thời thể hiện hoạt tính ức chế vi khuẩn trên sản phẩm thịt đùi heo bảo quản $10^{\circ} \mathrm{C}$ trong 7 ngày.

Trong nghiên cứu này của chúng tôi, hệ nhũ tương nano tinh dầu tiêu đen được tạo thành bằng phương pháp đồng hóa tốc độ cao (9000 vòng/phút) với kết quả tạo được hệ nhũ tương nano có kích thước trung bình giọt nhũ 61,9nm và chỉ số đa phân tán 0,462. (Ly \& Dong, 2019). Hệ nhũ tương này sau tạo thành được ứng dụng như dung dịch nhúng giúp bảo quản thịt gà và thịt heo tươi. Đồng thời để đa dạng hóa cách sử dụng của chế phẩm, hệ nhũ tương nano tinh dầu tiêu đen cũng được ướp trực tiếp vào thịt gà và thịt heo như một loại gia vị. Các sản phẩm thịt tươi nhúng bảo quản và thịt ướp sau khi sơ chế được bao gói và bảo quản lạnh ở $10^{\circ} \mathrm{C}$ trước khi đánh giá mức độ nhiễm vi sinh vật trong quá trình suốt thời gian bảo quản.

\section{Vật liệu và phương pháp nghiên cứu}

\subsection{Vật liệu}

Tinh dầu tiêu đen dùng trong nghiên cứu có nguồn gốc từ Ấn Độ, cung cấp bởi công ty Synthite Industrial Ltd. (India). Dầu nành tinh luyện Neptune mua từ siêu thị, được sản xuất bởi công ty Neptune Việt Nam. Chất nhũ hóa không ion polyoxyethylene sorbitan monooleate (Tween 80) được cung cấp bởi Biobasic (Canada).

Môi trường dùng nuôi cấy vi sinh vật hiếu khí bao gồm các thành phần: Tryptone (HIMEDIA, Ấn Độ), Cao nấm men (HIMEDIA, Ấn Độ), Glucose (GHTech, Trung Quốc), Agar (VIETXOCO, Việt Nam).

\section{tốc độ cao \\ 2.2. Quy trình tạo hệ nhũ tưong nano tinh dầu tiêu đen bằng phuơng pháp đồng hóa}

Dựa trên phương pháp tạo hệ nhũ tương nano bằng thiết bị đồng hóa tốc độ cao của một số các nghiên cứu trước đây của các nhóm tác giả Scholz và Keck (2015), Gharibzahedi và Mohammadnabi (2016), Mendes và cộng sự (2018). Quá trình tạo nhũ nano trong nghiên cứu được tiến hành qua hai giai đoạn. Đầu tiên, hệ nhũ tương thô được tạo thành. Chất nhũ hóa Tween 80 (10\% khối lượng hệ nhũ tương) và pha dầu gồm dầu nành và tinh dầu tiêu ( $20 \%$ khối lượng hệ nhũ tương; tỷ lệ tinh dầu: dầu nành=6:4) được trộn trên thiết bị khuấy từ ở tốc độ 600 vòng/ phút. Hỗn hợp vừa tạo thành được nhỏ giọt từ từ vào becher chứa nước cất trong điều kiện tốc độ khuấy 600 vòng/phút. Sau đó, hệ nhũ tương thô được đem đồng hóa tốc độ cao với thiết bị Silverson, Model L5T (Anh) ở tốc độ 9.000 vòng/phút trong thời gian 30 phút để tạo hệ nhũ tương nano tinh dầu tiêu đen. 


\subsection{Quy trình xử lý thịt tươi với hệ nhũ tưong nano tinh dầu tiêu đen}

Nhằm đánh giá hiệu quả của các chế phẩm nhũ tương nano tinh dầu từ các nguồn nguyên liệu thực vật khác nhau trên thực phẩm, các nhóm nghiên cứu chọn nhiều phương pháp nhúng, phun chế phẩm kết hợp đánh giá một số chỉ tiêu vi sinh vật. Trong nghiên cứu này sử dụng phương pháp ứng dụng bảo quản với hệ nhũ tương nano tinh dầu tiêu đen và đánh giá chỉ tiêu mật độ vi sinh vật hiếu khí dựa trên công bố của Ghani và cộng sự (2018), có thay đổi điều kiện thực hiện trong quá trình xử lý mẫu cho phù hợp điều kiện thí nghiệm.

Nguyên liệu thịt nạc tươi (ức gà, đùi heo) sau khi mua về sẽ được rửa sạch với nước cất vô trùng rồi để ráo trên rỗ nhựa đã được vô trùng, ở nhiệt độ phòng trong khoảng 15 phút. Sau đó thịt sẽ được cắt thành những miếng đồng nhất với kích thước $0,5 \times 3 \times 4 \mathrm{~cm}$ và được nhúng vào các dung dịch khác nhau để so sánh khả năng bất hoạt vi sinh vật hiếu khí (các dung dịch bao gồm: hệ nhũ tương nano tinh dầu tiêu đen, dung dịch nước muối $1 \%$ và nước cất vô trùng) trong khoảng thời gian 5 phút. Thịt sau khi nhúng các dung dịch được để ráo trên rỗ nhựa khoảng 15 phút, sau đó xếp thịt vào khay xốp và được bọc lại bằng màng bọc thực phẩm $\mathrm{PE}$. Các mẫu thịt sau xử lý và bao gói được đưa vào tủ lạnh bảo quản ở nhiệt độ $10^{\circ} \mathrm{C}$. Sau thời gian 2 ngày, 4 ngày, 6 ngày mẫu thịt được lấy ra và kiểm tra chỉ tiêu tổng vi sinh vật hiếu khí có trong thịt.

\subsection{Quy trình xử lý thịt uoớp gia vị với hệ nhũ tương nano tinh dầu tiêu đen}

Nhằm đa dạng hóa các ứng dụng bảo quản của hệ nhũ tương nano tinh dầu tiêu đen trên sản phẩm thịt, ngoài phương pháp nhúng thịt tươi vào dung dịch bảo quản, thịt tươi sau rửa và xử lý sẽ được ướp gia vị cùng với hệ nhũ tương nano tinh dầu tiêu đen. Sản phẩm được đóng gói, bao bọc với màng $\mathrm{PE}$ thực phẩm và bảo quản lạnh $10^{\circ} \mathrm{C}$ trước khi lấy mẫu phân tích chỉ tiêu mật độ vi sinh vật hiếu khí (Ghani et al., 2018).

Thịt gà và thịt heo tươi được chọn lựa tương tự ở thí nghiệm bảo quản thịt tươi trong mục 2.4. Sau giai đoạn cắt thịt thành từng miếng đồng nhất, thịt được ướp gia vị với $100 \mathrm{~g}$ thịt, hàm lượng gia vị tương ứng là: $1 \mathrm{~g}$ muối; $1 \mathrm{~g}$ nước mắm; $1 \mathrm{~g}$ bột ngọt; $0,5 \mathrm{~g}$ đường và $1 \mathrm{~g}$ dung dịch nano tinh dầu tiêu đen. Mẫu đối chứng không bổ sung thêm dung dịch nano tinh dầu tiêu đen. Sau khi ướp, thịt để yên trong trong khoảng 15 phút cho thấm gia vị, sau đó để ráo trên rỗ nhựa vô trùng trong khoảng 10 phút ở nhiệt độ phòng và xếp thịt vào khay xốp được bọc lại bằng màng bao thực phẩm $\mathrm{PE}$. Khay chứa thịt được bảo quản trong điều kiện lạnh $10^{\circ} \mathrm{C}$. Mẫu trong quá trình khảo sát sẽ được xác định tổng lượng vi sinh vật hiếu khí ở các thời điểm 3 ngày, 6 ngày, 9 ngày, 12 ngày để đánh giá khả năng bảo quản thịt của hệ nhũ tương nano tinh dầu tiêu đen.

\subsection{Phương pháp xác định tổng số vi sinh vật hiếu khí}

Mẫu thịt sau khi xử lý và bảo quản được cắt nhuyễn, pha loãng với dung dịch nước muối sinh lý vô trùng ở các độ pha loãng $10^{4}, 10^{5}, 10^{6}$ lần. Hút $0,5 \mathrm{ml}$ dịch pha loãng cho lên đĩa petri, thêm $20 \mathrm{ml}$ môi trường thạch Tryptone đã vô trùng ở $121^{\circ} \mathrm{C} / 15$ phút và để nguội đến khoảng $40^{\circ} \mathrm{C}$, lắc đều. Tiến hành ủ đĩa petri ở $37^{\circ} \mathrm{C} / 24$ giờ. Sau đó tiến hành đếm khuẩn lạc và tính toán tổng lượng vi sinh vật hiếu khí theo $\log _{10} \mathrm{CFU} / g$. (Ghani et al., 2018; Keykhosravy, Khanzadi, Hashemi, \& Azizzadeh, 2020; Xiong, Li, Warner, \& Fang, 2020; Huang et al., 2020).

\subsection{Phuơng pháp xử lý số liệu}

Số liệu thu được từ 3 lần lặp lại của các thí nghiệm sẽ được xử lý thống kê bằng phương pháp phân tích phương sai với phần mềm Stagraphic Ver. 3.0 để đánh giá sự khác biệt giữa các nghiệm thức trong thí nghiệm. 


\section{Kết quả và thảo luận}

\subsection{Khảo sát quá trình bảo quản thịt heo tươi với hệ nhũ tương nano tinh dầu tiêu đen}

Thịt đùi heo tươi sau khi được xử lý theo quy trình ở mục 2.4 và bảo quản ở nhiệt độ $10^{\circ} \mathrm{C}$ sẽ được đánh giá chỉ tiêu tổng số vi sinh vật hiếu khí $\left(\log _{10} \mathrm{CFU} / \mathrm{g}\right)$ ở các thời điểm 2,4 và 6 ngày. Mật độ vi sinh vật được xử lý thống kê bằng phương pháp phân tích phương sai để đánh giá mức độ nhiễm ở các dung dịch nhúng bảo quản khác nhau, kết quả được thể hiện trong Bảng 1.

\section{Bảng 1}

Mật độ vi sinh vật hiếu khí trên thịt heo bảo quản lạnh

\begin{tabular}{|c|c|c|c|}
\hline STT & Dung dịch nhúng & Ngày bảo quản & $\begin{array}{c}\text { Mật độ vi sinh vật hiếu khí } \\
\left(\log _{10} \mathrm{CFU} / \mathrm{g}\right)\end{array}$ \\
\hline 1 & \multirow{3}{*}{ Nhũ tương nano } & 2 & $5,40^{a} \pm 0,126$ \\
\hline 2 & & 4 & $5,92^{\mathrm{b}} \pm 0,099$ \\
\hline 3 & & 6 & $6,00^{\mathrm{bc}} \pm 0,144$ \\
\hline 4 & \multirow{3}{*}{ Nước muối 1\% } & 2 & $5,88^{\mathrm{b}} \pm 0,038$ \\
\hline 5 & & 4 & $6,06^{\mathrm{bcd}} \pm 0,128$ \\
\hline 6 & & 6 & $6,23^{d} \pm 0,196$ \\
\hline 7 & \multirow{3}{*}{ Nước cất } & 2 & $5,92^{\mathrm{b}} \pm 0,026$ \\
\hline 8 & & 4 & $6,07^{\mathrm{bcd}} \pm 0,144$ \\
\hline 9 & & 6 & $6,20^{\mathrm{cd}} \pm 0,097$ \\
\hline
\end{tabular}

Ghi chú: Trong cùng một cột, các số có cùng mẫu tự không khác biệt ở mức ý nghĩa 0,05

Nguồn: Kết quả xử lý từ dữ liệu điều tra

Kết quả phân tích phương sai cho thấy có sự khác biệt có ý nghĩa về mật độ vi sinh vật hiếu khí trong mẫu khi xử lý ở các dung dịch nhúng khác nhau và ở các ngày bảo quản khác nhau $(\mathrm{P}=$ $0,0000<0,05)$. Trong đó, sau 2 ngày bảo quản lạnh, các mẫu thịt heo tươi nhúng trong dung dịch nano tinh dầu tiêu cho mật độ vi sinh vật thấp nhất và khác biệt với hai dung dịch nhúng còn lại. Cụ thể là thấp hơn 0,48 và $0,52 \log _{10} \mathrm{CFU} / \mathrm{g}$ so với dung dịch nhúng là muối hay nước cất. Sau 4 ngày bảo quản, mật độ vi sinh vật hiếu khí của mẫu thịt heo tươi ở cả 3 phương pháp đều tăng lên, ở thời điểm này mật độ vi sinh vật hiếu khí ở các phương pháp dịch nhúng khác nhau không có sự khác biệt có ý nghĩa. Tiếp tục kéo dài thời gian bảo quản lên 6 ngày, trong khi mật độ vi sinh vật hiếu khí ở 2 phương pháp nhúng nước muối và nước cất tăng lên rất cao thì ở nghiệm thức nhúng trong dung dịch nano tinh dầu tiêu đen mật độ vi sinh vật vẫn không khác biệt so với ở ngày bảo quản thứ 4 .

Như vậy, với phương pháp xử lý với dung dịch nano tinh dầu tiêu đen các mẫu thịt heo tươi bảo quản lạnh có sự ức chế sự phát triển của vi sinh vật hiếu khí so với các phương pháp đối chứng bao gồm nhúng trong dung dịch nước muối $1 \%$ hay nhúng trong nước cất vô trùng. Kết quả này phù hợp với một số nghiên cứu xử lý thịt heo tươi với dung dịch nano nhũ tương tinh dầu. Theo nghiên cứu của Mendes và cộng sự (2018), hệ nhũ tương nano tinh dầu Eugenia brejoensis tạo thành bằng phương pháp đồng hóa tốc độ cao có khả năng ức chế Pseudomonas fluorescens với kết quả sau 5 ngày ủ với vi khuẩn này ở $10^{\circ} \mathrm{C}$, mật độ vi khuẩn trong thịt đùi heo nhúng dung dịch tinh dầu thấp hơn mẫu đối chứng không nhúng $1,8 \log _{10} \mathrm{CFU} / \mathrm{g}$. Trong một nghiên cứu khác 
của Xiong và cộng sự (2020), thịt sườn heo được nhúng dung dịch nano hỗn hợp có chứa tinh dầu kinh giới cay và pectin bảo quản ở $4^{\circ} \mathrm{C}$, sau 5 ngày mẫu đối chứng cho mật độ vi sinh vật hiếu khí là $5,8 \log _{10} \mathrm{CFU} / \mathrm{g}$ trong khí mẫu nhúng dung dịch mật độ $5 \log _{10} \mathrm{CFU} / \mathrm{g}$. Vì trong thí nghiệm của nhóm tác giả Xiong, chọn nhiệt độ bảo quản là $4^{\circ} \mathrm{C}$ và dùng loại tinh dầu khác, đồng thời có kết hợp thêm pectin giúp tăng khả năng bám của dịch nhúng lên mẫu thịt, nên mật độ vi sinh vật hiếu khí định lượng được thấp hơn so với mẫu thịt nhúng trong dung dịch nhũ tương nano tinh dầu tiêu đen trong nghiên cứu của chúng tôi (gần bằng $6 \log _{10} \mathrm{CFU} / \mathrm{g}$ ở ngày $5 \mathrm{khi}$ bảo quản ở $10^{\circ} \mathrm{C}$ so với $5 \log _{10} \mathrm{CFU} / \mathrm{g}$ ở ngày $5 \mathrm{khi}$ bảo quản $4^{\circ} \mathrm{C}$ ). Thời gian lưu mẫu càng dài thì theo số liệu trong nghiên cứu của Xiong và cộng sự (2020) cho thấy khả năng bảo quản của dung dịch chứa hệ nhũ tương nano càng thể hiện rõ, cụ thể là sau 15 ngày, mẫu nhúng dung dịch nano có mật độ vi sinh vật hiếu khí là $6,5 \log _{10} \mathrm{CFU} / \mathrm{g}$ trong khi mẫu đối chứng mật độ vi sinh vật tăng cao hơn nhiều và đạt mức $7,8 \log _{10} \mathrm{CFU} / \mathrm{g}$.

\subsection{Khảo sát quá trình bảo quản thịt gà tươ với hệ nhũ tưong nano tinh dầu tiêu đen}

Ngoài thịt heo, thịt gà cũng là loại thực phẩm ưa chuộng tại Việt Nam. Thịt gà cũng được xử lý tương tự thịt heo. Với kết quả mật độ vi sinh vật hiếu khí trong mẫu thịt ở các nghiệm thức được ghi nhận trong Bảng 2.

\section{Bảng 2}

Mật độ vi sinh vật hiếu khi trên thịt gà bảo quản lạnh

\begin{tabular}{|c|c|c|c|}
\hline STT & Dung dịch nhúng & Ngày bảo quản & $\begin{array}{c}\text { Mật độ vi sinh vật hiếu khí } \\
\left.\text { (Log } \log _{10} \mathrm{CFU} / \mathrm{g}\right)\end{array}$ \\
\hline 1 & \multirow{3}{*}{ Nhũ tương nano } & 2 & $5,62^{\mathrm{a}} \pm 0,049$ \\
\hline 2 & & 4 & $5,91^{\mathrm{bc}} \pm 0,030$ \\
\hline 3 & & 6 & $5,73^{\mathrm{ab}} \pm 0,427$ \\
\hline 4 & \multirow{3}{*}{ Nước muối 1\% } & 2 & $6,18^{\mathrm{cde}} \pm 0,096$ \\
\hline 5 & & 4 & $6,11^{\mathrm{cd}} \pm 0,061$ \\
\hline 6 & & 6 & $6,41^{\mathrm{e}} \pm 0,118$ \\
\hline 7 & \multirow{3}{*}{ Nước cất } & 2 & $6,21^{\mathrm{de}} \pm 0,038$ \\
\hline 8 & & 4 & $6,16^{\mathrm{cde}^{2}} \pm 0,123$ \\
\hline 9 & & 6 & $6,25^{\mathrm{de}} \pm 0,140$ \\
\hline
\end{tabular}

Ghi chú: Trong cùng một cột, các số có cùng mẫu tự không khác biệt ở mức ý nghĩa 0,05

Nguồn: Kết quả xử lý từ dữ liệu điều tra

Kết quả phân tích thống kê cho thấy có sự khác biệt có ý nghĩa về mật độ vi sinh vật trên mẫu ở các nghiệm thức dung dịch nhúng khác nhau và ở các thời điểm bảo quản khác nhau $(\mathrm{P}=0,0002<0,05)$. Kết quả này có những điểm tương đồng với kết quả khi xử lý mẫu thịt heo bảo quản lạnh như sau 2 ngày bảo quản mẫu thịt gà nhúng dung dịch nano tinh dầu tiêu đen vẫn là mẫu có mật độ vi sinh vật hiếu khí thấp nhất và khác biệt so với các mẫu cùng ngày với phương pháp bảo quản khác. Tuy nhiên, vi sinh vật hiếu khí trong các mẫu thịt gà không nhúng dung dịch nano tinh dầu tiêu đen có sự gia tăng nhanh về mật độ so với thịt heo, sau 4 ngày bảo quản lạnh, mật độ vi sinh vật ở các mẫu thịt gà đều vượt giá trị $6 \log _{10} \mathrm{CFU} / \mathrm{g}$. Và sau 6 ngày bảo quản, các mẫu thịt gà nhúng dung dịch nano tinh dầu, mật độ vi sinh vật hiếu khí vẫn duy trì ở mức $5,73 \log _{10} \mathrm{CFU} / \mathrm{g}$ chưa vượt qua giá trị $6 \log _{10} \mathrm{CFU} / \mathrm{g}$ như các phương pháp nhúng khác. 
Trong các nghiên cứu nhúng thịt gà trong dung dịch nhũ tương tinh dầu nano cũng cho thấy một số kết quả khả quan cho ứng dụng này. Trong nghiên cứu của Noori và cộng sự (2018), tổng số vi khuẩn chịu lạnh được đo đạc sau khi nhúng fillet gà vào các dung dịch khác nhau gồm nước cất vô trùng (đối chứng), dung dịch nhũ tương thô và dung dịch nhũ tương nano cùng chứa $6 \%$ tinh dầu gừng, kết quả cho thấy sau 12 ngày bảo quản ở $4^{\circ} \mathrm{C}$ mật độ vi khuẩn lần lượt là 6,5 ; 4,59 và $2,8 \log _{10} \mathrm{CFU} / \mathrm{g}$. Như vậy hệ nhũ tương nano tinh dầu gừng cho hiệu quả bảo quản rõ rệt so với mẫu đối chứng và nhũ tương thô chứa cùng hàm lượng tinh dầu. Hai loại tinh dầu Zataria multiflora Boiss và Bunium persicum Boiss được tiến hành tạo nhũ tương nano có kết hợp chitosan với hàm lượng $1 \%$ tinh dầu để nhúng thịt gà tây trong nghiên cứu của Keykhosravy và cộng sự (2020). Kết quả cho thấy sau 6 ngày bảo quản ở $4^{\circ} \mathrm{C}$ mật độ vi sinh vật hiếu khí trong mẫu đối chứng không nhúng dung dịch bảo quản là 7,23 $\log _{10} \mathrm{CFU} / \mathrm{g}$, trong khi ở hai dung dịch chứa riêng lẻ hai loại tinh dầu trên lần lượt thấp hơn mẫu đối chứng 2,06 và $1,81 \log _{10} \mathrm{CFU} / \mathrm{g}$ và sự khác biệt này có ý nghĩa thống kê.

Như vậy với kết quả khảo sát ở hai thí nghiệm bảo quản thịt tươi nhúng trong các dung dịch cho thấy hệ nhũ tương nano tinh dầu tiêu đen có thể sử dụng hiệu quả hơn và giúp giảm mức độ gia tăng mật độ vi sinh vật hiếu khí trên thịt gà và thịt heo tươi trong quá trình bảo quản lạnh $10^{\circ} \mathrm{C}$ so với các mẫu chỉ nhúng trong nước cất hay nước muối loãng $1 \%$. Thời gian bảo quản tốt nhất ở điều kiện đang xét là dưới 4 ngày bảo quản lạnh cho thịt tươi, cả gà và heo.

\section{tiêu đen \\ 3.3. Khảo sát quá trình bảo quản thịt heo wớp gia vị với hệ nhũ tương nano tinh dầu}

Thịt heo sau khi xử lý, ướp gia vị, bảo quản lạnh theo quy trình ở mục 2.5 sẽ được phân tích chỉ tiêu tổng vi sinh vật hiếu khí, kết quả được ghi nhận trong Bảng 3.

\section{Bảng 3}

Mật độ vi sinh vật hiếu khí trên thịt heo ướp gia vị bảo quản lạnh

\begin{tabular}{|c|c|c|c|}
\hline STT & Đặc điểm công thức gia vị ướp & Ngày bảo quản & $\begin{array}{c}\text { Mật độ vi sinh vật hiếu khí } \\
\left(\log _{10} \mathrm{CFU} / \mathrm{g}\right)\end{array}$ \\
\hline 1 & \multirow{4}{*}{$\begin{array}{l}\text { Bổ sung nhũ tương nano tinh } \\
\text { dầu tiêu đen }\end{array}$} & 3 & $5,39^{\mathrm{a}} \pm 0,027$ \\
\hline 2 & & 6 & $5,64^{\mathrm{b}} \pm 0,122$ \\
\hline 3 & & 9 & $5,94^{\mathrm{c}} \pm 0,023$ \\
\hline 4 & & 12 & $6,32^{\mathrm{f}} \pm 0,025$ \\
\hline 5 & \multirow{4}{*}{$\begin{array}{l}\text { Không bổ sung nhũ tương nano } \\
\text { tinh dầu tiêu đen }\end{array}$} & 3 & $6,10^{\mathrm{d}} \pm 0,091$ \\
\hline 6 & & 6 & $6,15^{\mathrm{de}} \pm 0,061$ \\
\hline 7 & & 9 & $6,11^{\mathrm{d}} \pm 0,110$ \\
\hline 8 & & 12 & $6,24^{\mathrm{ef}} \pm 0,048$ \\
\hline
\end{tabular}

Ghi chú: Trong cùng một cột, các số có cùng mẫu tự không khác biệt ở mức ý nghĩa 0,05

Nguồn: Kết quả xử lý từ dữ liệu điều tra

Dựa trên kết quả phân tích phương sai cho thấy có sự khác biệt có ý nghĩa về mật độ vi sinh vật hiếu khí khi bảo quản với thịt heo ướp gia vị có và không bổ sung dung dịch nano tinh dầu tiêu đen ở các thời điểm bảo quản khác nhau (số liệu được xử lý với 3 lần lặp lại ở tất cả các nghiệm thức với $\mathrm{P}=0,0000<0,05)$. Trong thời gian bảo quản 12 ngày ở $10^{\circ} \mathrm{C}$, có sự gia tăng mật 
độ vi sinh vật trong cả hai công thức ướp, trong đó, công thức ướp có bổ sung hệ nhũ tương nano tinh dầu tiêu đen cho thấy sự gia tăng mật độ vi sinh vật chậm hơn và sự khác biệt này có ý nghĩa thống kê. Cụ thể là trong thời gian từ 3 đến 9 ngày, mật độ vi sinh vật của công thức ướp có hệ nhũ tương nano tinh dầu đều dưới $6 \log _{10} \mathrm{CFU} / \mathrm{g}$, phải đến 12 ngày bảo quản, mẫu thịt heo của công thức này mới có sự tăng mật độ vi sinh vật lên $6,32 \log _{10} \mathrm{CFU} / \mathrm{g}$. Trong khi công thức ướp gia vị không chứa nano tinh dầu tiêu mật độ vi sinh vượt $6 \log _{10} \mathrm{CFU} / \mathrm{g}$ ngay tại ngày thứ 3 bảo quản lạnh $10^{\circ} \mathrm{C}$. Như vậy với phương pháp bảo quản ướp thịt cùng với hệ nhũ tương nano tinh dầu tiêu đen có thể bảo quản thịt heo có gia vị tốt hơn trong khoảng 9 ngày ở $10^{\circ} \mathrm{C}$ so với mẫu không sử dụng hệ nhũ tương nano tinh dầu tiêu đen.

Trong một nghiên cứu sử dụng hệ nhũ tương nano tinh dầu cho thị có qua chế biến của Liu, Zhang, Bhandari, Xu, và Yang (2020). Nhóm tác giả chế biến thịt chế biến ăn liền có nhúng một số dung dịch trong quá trình chế biến bao gồm các mẫu thịt không nhúng, thịt nhúng dung dịch nhũ tương có tinh dầu đại hồi $0,6 \%$ kết hợp chất kháng khuẩn polylysine và nisin và dung dịch kết hợp cùng công thức như trên nhưng ở trạng thái nhũ tương nano. Mẫu sau chế biến được bảo quản $4^{\circ} \mathrm{C}$ và đánh giá chỉ tiêu mật độ vi sinh vật hiếu khí. Kết quả cho thấy sau 12 ngày bảo quản mật độ vi sinh vật lần lượt là 5,$8 ; 4,0$ và $3,0 \log _{10} \mathrm{CFU} / \mathrm{g}$ cho các mẫu đối chứng, nhũ tương thô và nhũ tương nano. Mật độ vi sinh vật này thấp hơn so với kết quả của chúng tôi do mẫu có bổ sung thêm các chất kháng khuẩn cũng như bảo quản ở nhiệt độ thấp hơn $\left(4^{\circ} \mathrm{C}\right.$ so với $\left.10^{\circ} \mathrm{C}\right)$. Tuy nhiên kết quả cũng đưa ra được khả năng bảo quản tốt của hệ nhũ tương nano cho thịt qua sơ chế và chế biến. tiêu đen

3.4. Khảo sát quá trình bảo quản thịt gà wớp gia vị với hệ nhũ tương nano tinh dầu

Thịt gà cũng được xử lý theo quy trình 2.5, được ướp gia vị cùng dung dịch nano tinh dầu tiêu đen để so sánh với mẫu chỉ ướp gia vị. Kết quả thể hiện trong Bảng 4.

\section{Bảng 4}

Mật độ vi sinh vật hiếu khi trên thịt gà ướp gia vị bảo quản lạnh

\begin{tabular}{|c|c|c|c|}
\hline STT & Đặc điểm công thức gia vị ướp & Ngày bảo quản & $\begin{array}{c}\text { Mật độ vi sinh vật hiếu khí } \\
\text { (Log10CFU/g) }\end{array}$ \\
\hline 1 & \multirow{4}{*}{$\begin{array}{l}\text { Bổ sung nhũ tương nano tinh dầu } \\
\text { tiêu đen }\end{array}$} & 3 & $5,37^{a} \pm 0,041$ \\
\hline 2 & & 6 & $5,54^{\mathrm{b}} \pm 0,048$ \\
\hline 3 & & 9 & $5,99^{c} \pm 0,079$ \\
\hline 4 & & 12 & $6,11^{\mathrm{cd}} \pm 0,035$ \\
\hline 5 & \multirow{4}{*}{$\begin{array}{l}\text { Không bổ sung nhũ tương nano } \\
\text { tinh dầu tiêu đen }\end{array}$} & 3 & $6,10^{\mathrm{cd}} \pm 0,097$ \\
\hline 6 & & 6 & $6,21^{\mathrm{d}} \pm 0,125$ \\
\hline 7 & & 9 & $6,16^{\mathrm{d}} \pm 0,078$ \\
\hline 8 & & 12 & $6,14^{\mathrm{d}} \pm 0,051$ \\
\hline
\end{tabular}

Ghi chú: Trong cùng một cột, các số có cùng mẫu tự không khác biệt ở mức ý nghĩa 0,05

Nguồn: Kết quả xử lý từ dữ liệu điều tra

Kết quả phân tích phương sai so sánh mật độ vi sinh vật hiếu khí trong thịt gà với hai phương pháp ướp (có và không có dung dịch nano tinh dầu tiêu đen) ở các thời gian bảo quản khác nhau cũng cho thấy có sự khác biệt có ý nghĩa thống kê $(\mathrm{P}=0,0000<0,05)$. Kết quả ghi nhận cho 
thấy sự tương đồng với thí nghiệm bảo quản thịt heo ướp gia vị (Bảng 3), vì công thức ướp của hai thí nghiệm hoàn toàn giống nhau ở hai nguyên liệu thịt. Từ 3 đến 9 ngày bảo quản lạnh có sự gia tăng mật độ vi sinh vật trong mẫu thịt gà ướp cùng hệ nhũ tương nano tinh dầu tiêu đen, tuy nhiên ở ngày thứ 9 , mật độ vi sinh vật vẫn chưa vượt $6 \log _{10} \mathrm{CFU} / \mathrm{g}$. Trong khi ở công thức ướp đối chứng chỉ có gia vị, không bổ sung hệ nhũ tương nano tinh dầu tiêu đen, từ ngày thứ 3 , mật độ vi sinh vật đã là $6,10 \log _{10} \mathrm{CFU} / \mathrm{g}$. Như vậy, thịt gà ướp gia vị có bổ sung hệ nhũ tương nano tinh dầu tiêu đen có thể bảo quản tốt hơn mẫu thịt có gia vị và không ướp hệ nhũ tương nano tinh dầu tiêu đen trong khoảng thời gian 9 ngày ở nhiệt độ lạnh $10^{\circ} \mathrm{C}$. Sau thời điểm này, mật độ vi sinh vật hiếu khí cả hai mẫu đều tăng nhanh và không khác biệt thống kê. So sánh với một nghiên cứu với sản phẩm thịt gà chế biến ăn liền của Huang và cộng sự (2020) cũng cho thấy hiệu quả tương tự, thịt gà được chế biến có nhúng hệ nhũ tương thô và hệ nhũ tương nano cùng chứa các thành phần gelatin - chitosan - chất trích lá hương thảo, để so sánh có thực hiện mẫu đối chứng không nhúng. Sau 16 ngày bảo quản $4^{\circ} \mathrm{C}$, mật độ vi sinh vật hiếu khí giảm dần theo thứ tự mẫu đối chứng, nhũ tương và nhũ tương nano cụ thể là 6,$69 ; 5,73$ và $5,31 \log _{10} \mathrm{CFU} / \mathrm{g}$.

\section{Kết luận}

Hệ nhũ tương nano tinh dầu tiêu đen tạo thành bằng phương pháp đồng hóa tốc độ cao trong nghiên cứu có thể được ứng dụng vào quá trình bảo quản thịt tươi và cả thịt ướp gia vị. Kết quả nghiên cứu cho thấy khi nhúng thịt tươi (heo và gà) vào chế phẩm trong 5 phút có khả năng làm giảm tốc độ phát triển của vi sinh vật hiếu khí so với các mẫu đối chứng không nhúng trong dung dịch nano tinh dầu, thời gian bảo quản cho sản phẩm thịt tươi tạo nên sự khác biệt là dưới 4 ngày bảo quản lạnh ở $10^{\circ} \mathrm{C}$. Đối với sản phẩm thịt có ướp gia vị, sản phẩm bổ sung thêm chế phẩm với nồng độ $1 \%$ so với thịt giúp bảo quản thịt tốt hơn các mẫu đối chứng chỉ ướp gia vị (9 ngày so với 3 ngày) cũng ở nhiệt độ $10^{\circ} \mathrm{C}$.

\section{LÒ̀I CẢM ƠN}

Nhóm tác giả chân thành cảm ơn sự hỗ trợ kinh phí cho nghiên cứu của Trường Đại Học Mở Thành phố Hồ Chí Minh. Cảm ơn sự quan tâm, hỗ trợ các thiết bị, dụng cụ và các tài nguyên khác của Phòng thí nghiệm Công nghệ thực phẩm thuộc Khoa Công Nghệ sinh học trường Đại học Mở Thành phố Hồ Chí Minh giúp chúng tôi hoàn thành nghiên cứu này.

\section{Tài liệu tham khảo}

Bastos, L. P. H., Vicente, J., dos Santos, C. H. C., de Carvalho, M. G., \& Garcia-Rojas, E. E. (2020). Encapsulation of black pepper (Piper nigrum L.) essential oil with gelatin and sodium alginate by complex coacervation. Food Hydrocolloids, 102, 105-605. doi:10.1016/j.foodhyd.2019.105605

Ghani, S., Barzegar, H., Noshad, M., \& Hojjati, M. (2018). The preparation, characterization and in vitro application evaluation of soluble soybean polysaccharide films incorporated with cinnamon essential oil nanoemulsions. International Journal of Biological Macromolecules, 112, 197-202. doi:10.1016/j.ijbiomac.2018.01.145

Gharenaghadeh, S., Karimi, N., Forghani, S., Nourazarian, M., Gharehnaghadeh, S., Jabbaria, V., ... Kafil, H. S. (2017). Application of Salvia multicaulis essential oil-containing nanoemulsion against food-borne pathogens. Food Bioscience, 19, 128-133. 
Gharibzahedi, S. M. T., \& Mohammadnabi, S. (2016). Characterizing the novel surfactantstabilized nanoemulsions of stinging nettle essential oil: Thermal behaviour, storage stability, antimicrobial activity and bioaccessibility. Journal of Molecular Liquids, 224, 1332-1340. doi:10.1016/j.molliq.2016.10.120

Huang, M., Wang, H., Xu, X., Lu, X., Song, X., \& Zhou, G. (2020). Effects of nanoemulsionbased edible coatings with composite mixture of rosemary extract and $\varepsilon$-poly-L-lysine on the shelf life of ready-to-eat carbonado chicken. Food Hydrocolloids, 102, 105-576. doi:10.1016/j.foodhyd.2019.105576

Jimenez, M., Domínguez, J. A., Pascual-Pineda, L. A., Azuara, E., \& Beristain, C. I. (2018). Elaboration and characterization of $\mathrm{O} / \mathrm{W}$ cinnamon (Cinnamomum zeylanicum) and black pepper (Piper nigrum) emulsions. Food Hydrocolloids, 77, 902-910. doi:10.1016/j.foodhyd.2017.11.037

Keykhosravy, K., Khanzadi, S., Hashemi, M., \& Azizzadeh, M. (2020). Chitosan-loaded nanoemulsion containing Zataria Multiflora Boiss and Bunium persicum Boiss essential oils as edible coatings: Its impact on microbial quality of turkey meat and fate of inoculated pathogens. International Journal of Biological Macromolecules, 150, 904-913. doi:10.1016/j.ijbiomac.2020.02.092

Li, Y., Zhang, C., Pan, S., Chen, L., Liu, M., Yang, K., ...Tian, J. (2020). Analysis of chemical components and biological activities of essential oils from black and white pepper (Piper nigrum L.) in five provinces of southern China. LWT - Food Science and Technology, 117, 108644. doi:10.1016/j.lwt.2019.108644

Liu, Q., Zhang, M., Bhandari, B., Xu, J., \& Yang, C., (2020). Effects of nanoemulsion-based active coatings with composite mixture of star anise essential oil, polylysine, and nisin on the quality and shelf life of ready-to-eat Yao meat products. Food Control, 107, 106771. doi:10.1016/j.foodcont.2019.106771

Lou, Z., Chen, J., Yu, F., Wang, H., Kou, X., Ma, C., \& Zhu, S. (2017). The antioxidant, antibacterial, antibiofilm activity of essential oil from Citrus medica L. var. sarcodactylis and its nanoemulsion, LWT - Food Science and Technology, 80, 371-377. doi:10.1016/j.lwt.2017.02.037

Ly, H. T. M, \& Dong, D. T. A. (2019). Formation of nanoemulsion from black pepper essential oil by high speed homogenization method. Vietnam Journal of Chemistry, 57(3), 352-356. doi:10.1002/vjch.201900033

Mendes, J. F., de Abreu Martinsa, H. H., Otonib, C. G., Santanac, N. A., Silvac, R. C. S., da Silvad, A. G., ...de Oliveira, J. E. (2018). Chemical composition and antibacterial activity of Eugenia brejoens is essential oil nanoemulsions against Pseudomonas fluorescens. LWT - Food Science and Technology, 93, 659-664. doi:10.1016/j.lwt.2018.04.015

Moraes-Lovison, M., Marostegan, L. F. P., Peres, M. S., Menezes, I. F., Ghiraldi, M., Rodrigues, R. A. F., ...Pinho, S. C. (2017). Nanoemulsions encapsulating oregano essential oil: Production, stability, antibacterial activity and incorporation in chicken pate. LWT - Food Science and Technology, 77, 233-240. doi:10.1016/j.lwt.2016.11.061

Myszka, K., Schmidt, M. T., Majcher, M., Juzwa, W., \& Czaczyk, K. (2017). $\beta$-Caryophyllenerich pepper essential oils suppress spoilage activity of Pseudomonas fluorescens KM06 in fresh-cut lettuce. LWT - Food Science and Technology, 83, 118-126. doi:10.1016/j.lwt.2017.05.012 
Noori, S., Zeynali, F., \& Almasi, H. (2018). Antimicrobial and antioxidant efficiency of nanoemulsion-based edible coating containing ginger (Zingiber officinale) essential oil and its effect on safety and quality attributes of chicken breast fillets. Food Control, 84, 312320. doi:10.1016/j.foodcont.2017.08.015

Rakmai, J., Cheirsilp, B., Mejuto, J. C., Torrado-Agrasar, A., \& Simal-Gandara, J. (2017). Physico-chemical characterization and evaluation of bio-efficacies of black pepper essential oil encapsulated in hydroxypropyl-betacyclodextrin. Food Hydrocolloids, 65, 157-164. doi:10.1016/j.foodhyd.2016.11.014

Scholz, P., \& Keck, C. M. (2015). Nanoemulsions produced by rotor-stator high speed stirring. International Journal of Pharmaceutics, 482, 110-117. doi:10.1016/j.ijpharm.2014.12.040

Shadman, S., Hosseini, S. E., Langroudi, H. E., \& Shabani, S. (2017). Evaluation of the effect of a sunflower oil-based nanoemulsion with Zataria multiflora Boiss essential oil on the physicochemical properties of rainbow trout (Oncorhynchus mykiss) fillets during cold storage. LWT - Food Science and Technology, 79, 511-517. doi:10.1016/j.lwt.2016.01.073

Shokri, S., Parastouei, K., Taghdir, M., \& Abbaszadeh, S. (2020). Application an edible active coating based on chitosan - Ferulago angulata essential oil nanoemulsion to shelf life extension of Rainbow trout fillets stored at $4^{\circ} \mathrm{C}$. International Journal of Biological Macromolecules, 153, 846-854. doi:10.1016/j.ijbiomac.2020.03.080

Stojanovic-Radic, Z., Pejcic, M., Jokovi, N., Jokanovi, M., Ivi, M., Sojic, B., ...Mihajilov-Krstev, T. (2018). Inhibition of Salmonella Enteritidis growth and storage stability in chicken meat treated with basil and rosemary essential oils alone or in combination. Food Control, 90, 332-343. doi:10.1016/j.foodcont.2018.03.013

Swathy, J. S., Mishra, P., Thomas, J., Mukherjee, A., \& Chandrasekaran, N. (2018). Antimicrobial potency of high-energy emulsified black pepper oil nanoemulsion against aquaculture pathogen. Aquaculture, 491, 210-220. doi:10.1016/j.aquaculture.2018.03.045

Xiong, Y., Li, S., Warner, R. D., \& Fang, Z. (2020). Effect of oregano essential oil and resveratrol nanoemulsion loaded pectin edible coating on the preservation of pork loin in modified atmosphere packaging. Food Control, 114, 107226. doi:10.1016/j.foodcont.2020.107226

Zhang, J., Wang, Y., Pan, D., Cao, J.-X., Shao, X.-F., Chen, Y.-J., ...Ou, C.-R. (2016). Effect of black pepper essential oil on the quality of fresh pork during storage. Meat Science, 117, 130-136. doi:10.1016/j.meatsci.2016.03.002 